\title{
Experimental research in rats on the reactivity of new corneal blood vessels to adrenaline
}

\author{
Daniela Bianca Damian*, Aurelian Mihai Ghiță**, Sânziana Istrate***, Ioana Cristina Coman**** \\ *Department of Ophthalmology, “Dr. Alexandru Popescu” Military Emergency Hospital Focșani, \\ Focșani, Vrancea, Romania \\ **Department of Physiology, “Carol Davila” University of Medicine and Pharmacy, Bucharest, Romania \\ ***Department of Ophthalmology, “Carol Davila” University of Medicine and Pharmacy, Bucharest, Romania \\ ****Department of Ophthalmology, Medsana Medical Center, Bucharest, Romania
}

Correspondence to: Daniela Bianca Damian,

Department of Ophthalmology, "Dr. Alexandru Popescu” Military Emergency Hospital Focșani,

3-5 Cezar Bolliac Street, Focșani, Code: 620167, Vrancea, Romania,

Mobile phone: +40722421111, E-mail: danibiatravel@yahoo.com

Accepted: February 4th, 2021

\begin{abstract}
Aim: The purpose of this experimental study was to evaluate the existence of adrenergic receptors in ketamine-induced corneal blood vessels in rat pups.

Methods: The study of corneal neovascularization motricity was performed on 45-day-old Wistar rats in which, starting from the 15th day of life, corneal blood vessels were obtained by injecting intraperitoneal ketamine at a dose of $150 \mathrm{mg} / \mathrm{kg}$ body weight, a total of 5 successive doses. The examination of the neovascularization was done with the help of a Nikon stereomicroscope connected to a video camera and a computer, the total magnification being $400 \mathrm{X}$. The reactivity of the new corneal blood vessels to the administration in conjunctival instillations of a $1.5 \mathrm{mmol} / \mathrm{L}$ adrenaline solution was tested. The parameters followed were represented by variations in the caliber of corneal blood vessels. The data were analyzed using Microsoft Office Excel.

Results: Administration of distilled water did not produce statistically significant changes in corneal blood vessels, while adrenaline produced a statistically significant constriction of vascular diameter ( $\mathrm{p}=0.01$ at $\mathrm{T} 9, \mathrm{p}=0.004$ at $\mathrm{T} 10, \mathrm{p}=0.019$ at time $\mathrm{T} 11$ of examinations).

Conclusions: The results showed that adrenaline produces vasoconstriction in the new corneal blood vessels, which allows us to assume that they contain $\alpha$-adrenergic receptors. However, we cannot say that corneal pathological vessels do not contain $\beta 2$-type adrenergic receptors, because the effect of adrenaline may be an algebraic sum between vasoconstriction produced by stimulating $\alpha$-adrenergic receptors and vasodilation produced by stimulating $\beta 2$-adrenergic receptors, but in which the vasodilating effect may be masked by the vasoconstrictor effect given by a higher density of $\alpha$-adrenergic receptors.

Keywords: adrenaline, new blood vessels, cornea, vasoconstriction

Abbreviations: $\mathrm{A}=$ adrenaline, $\mathrm{DNM}=$ non-measurable diameter, $\mathrm{NA}=$ noradrenaline, Std.Er.= Standard error
\end{abstract}

\section{Introduction}

The adrenergic system comprises all the structures that use the catecholamines adrenaline and noradrenaline as chemical mediators. First described by Ahlquist in 1948 [1], adrenergic receptors are divided into two categories: $\alpha$-adrenergic receptors and $\beta$-adrenergic receptors. Subsequently, the subtypes $\alpha 1$ with postsynaptic localization and $\alpha 2$ located predominantly presynaptic, but also postsynaptic and extrasynaptic were highlighted for $\alpha$-adrenergic receptors [2-4]. $\alpha$-adrenergic receptors were also divided into several sub-types $\beta 1, \beta 2, \beta 3$, and $\beta 4$ [5-7]. In 1959, Furchgott discovered other types of adrenergic receptors, gamma, and delta [8], responsible for the actions of catecholamines in smooth muscles. Currently, most authors admitted the existence of $\alpha 1-, \alpha 2-, \beta 1$ - and $\beta 2$-adrenergic receptors. $\alpha 1$-adrenergic receptors are found mainly in the vascular smooth muscles, and their stimulation 
causes vasoconstriction. $\alpha 2$-adrenergic receptors are located mainly presynaptically, and their stimulation inhibits presynaptic release of norepinephrine leading to relaxation of vascular and intestinal smooth muscles. There are also postsynaptic $\alpha 2$ receptors that cause vasoconstriction [9]. Stimulation of $\beta 2$-adrenergic receptors causes vasodilation by relaxing the vascular smooth muscles (arteriolar and venous).

The corneal epithelium expresses $\alpha$ - and $\beta$-type adrenergic receptors. $\beta$-adrenergic receptors are found at the cell surface, and through adenylate cyclase, leading to the formation of AMP-cyclic, with stimulation of $\mathrm{Cl}$ - permeability at the epithelial membrane [10], as well as $\alpha 1$-adrenergic receptors that regulate inositol-phosphate turnover [11]. Stimulation of corneal $\beta$-adrenergic receptors causes protein kinase $A$ activation and an increase in intracellular cAMP concentration, and stimulation of $\alpha 2$-adrenergic receptors inhibits protein kinase $\mathrm{A}$ (PKA) activity by inhibiting adenylate cyclase. Modulation of the corneal cAMP-PKA pathway can play important roles in homeostasis and corneal wound healing [12].
The effects of adrenaline and noradrenaline depend on their selectivity to the types of adrenergic receptors, as well as the density of the types of adrenergic receptors in the tissues. Noradrenaline has a high affinity for $\alpha$-adrenoreceptors, causing a pressor-type response. Noradrenaline causes vasoconstriction in all vascular territories and increased volume by contraction of the spleen capsule [9]. Adrenaline has an affinity for both types of receptors, thus determining biphasic actions, the final response depending on the types of receptors it binds to and their density at the cell surface. Thus, in the cutaneous, mucosal, and splanchnic territories, where there is a higher density of $\alpha 1$-adrenergic receptors, adrenaline leads to vasoconstriction, while in the brain, in striated muscles, kidneys, or coronary adrenaline causes vasodilation due to an increased density of $\beta 2$-adrenergic receptors. Table 1 shows a distribution of adrenergic receptors in the ocular tissues (in humans), and Table 2 shows a classification of adrenoceptors with agonists (endogenous and exogenous) and antagonists.

Table 1. Distribution of adrenergic receptors in human eye tissues

\begin{tabular}{ll}
\multicolumn{1}{c}{$\begin{array}{c}\text { Type of } \\
\text { adrenergic } \\
\text { receptor }\end{array}$} & \multicolumn{1}{c}{ Tissue location } \\
$\alpha 1$ & - iris dilator muscle [13]; retinal blood vessels [14]; ciliary muscle [15]; conjunctival epithelium \\
$\alpha 2$ & [16]; corneal epithelium [11] and endothelium [17] \\
& - retinal pigmented epithelium- choriocapillaris, neurosensory retina [18]; iris epithelium and \\
& ciliary epithelium [18,19]; ciliary muscle [19]; retinal blood vessels [14]; retina (ganglion cells, \\
& and cells in the inner and outer nuclear layers) [20]; conjunctival epithelial cells [16,21]; \\
$\beta 1$ & trabecular meshwork cells [22] \\
$\beta 2$ & - iris-ciliary body (small number) [23]; conjunctival epithelium [16]; retinal blood vessels [24] \\
$\beta 3$ & - ciliary muscle [15]; trabecular meshwork cells [25-27]; corneal epithelium and endothelium, lens \\
& epithelium, retina [27]; conjunctival epithelium [16,27]
\end{tabular}

Table 2. Classification of adrenergic receptors with agonists (endogenous and exogenous) and antagonists

\begin{tabular}{|c|c|c|c|}
\hline $\begin{array}{l}\text { Type of } \\
\text { adrenergic } \\
\text { receptor }\end{array}$ & Agonists (endogenous) & Selective agonists (exogenous) & Selective antagonists \\
\hline$\alpha 1$ & $\mathrm{NA}=\mathrm{A}[29,30]$ & $\begin{array}{l}\text {-phenylephrine [31] } \\
\text {-methoxamine [32] }\end{array}$ & $\begin{array}{l}\text {-prazosin }[33] \\
\text {-doxazosin }[33,34] \\
\text {-terazosin }[33,34] \\
\text {-tamsulosin }[34]\end{array}$ \\
\hline$\alpha 2$ & $\mathrm{~A}=\mathrm{NA}[30,31]$ & $\begin{array}{l}\text {-clonidine [35] } \\
\text {-dexmedetomidine [35] } \\
\text {-oxymetazoline [31] }\end{array}$ & -yohimbine [35] \\
\hline$\beta 1$ & $\mathrm{NA}=\mathrm{A}[36]$ & -dobutamine [37] & $\begin{array}{l}\text {-metoprolol }[38,39] \\
\text {-atenolol }[38,39] \\
\text {-bisoprolol }[38,39]\end{array}$ \\
\hline$\beta 2$ & $\mathrm{~A}>\mathrm{NA}[36]$ & $\begin{array}{l}\text {-fenoterol }[\mathbf{4 0}] \\
\text {-terbutaline }[\mathbf{4 0}] \\
\text {-salbutamol }[\mathbf{4 0}]\end{array}$ & -Butoxamine [41] \\
\hline$\beta 3$ & $\mathrm{NA}>\mathrm{A}[36]$ & -mirabegron [42] & -SR59230A [43] \\
\hline
\end{tabular}


In certain situations, ocular neovascularization can lead to impaired visual function as well as the loss of the eyeball. The study of pharmacological receptors developed in the new blood vessels remains a challenge for the discovery of drug active substances, without/with minimal side effects, which may lead to their stopping or regression.

\section{Material and method}

The experiments were performed on Wistar rats. The animals were provided by the Biobase of "Carol Davila" University of Medicine and Pharmacy, Bucharest. The batches of animals were brought to the working laboratory where they were kept in standard environmental conditions. The animals had ad libitum access to food and water and were housed in plexiglass cages. The ambient temperature was between 21 and $24{ }^{\circ} \mathrm{C}$, and the relative humidity was maintained between 45 and $60 \%$.

The experiment started with 75 rat pups, aged 15 days, in which corneal blood vessels were obtained by successive administration of ketamine at a dose of $150 \mathrm{mg} / \mathrm{kg}$ body weight, at an interval of 5 days between administrations, a total of five doses, to obtain a possible experimental model of corneal neovascularization. After the fifth dose of ketamine, rats with at least one eye neovascularization were selected, so that 19 batches of animals were formed, each batch of 6 eyes/experiment evaluable from the point of view of corneal neovascularization, on which adrenergic, cholinergic, and histaminergic substances were tested. The batch on which the adrenaline was tested was composed of 4 animals/ 6 eyes with neovascularization. The testing of the reactivity of new corneal blood vessels to adrenergic substances was performed on 45-day-old rats weighing 47-75 grams, in which corneal blood vessels were obtained by the method described above. Recordings were made for each eye with neovascularization, 6 eyes for each experiment.

The experiments were carried out with the approval of the Ethics Commission of "Carol Davila" University of Medicine and Pharmacy Bucharest, as well as following the provisions of Directive 2010/ 63 / EU on the protection of animals used for scientific purposes, as well as their transposition into national law, by Law No. 43/ 2014.

The substances used were ketamine $10 \%$ solution (CP-Ketamine 10\%, CP-Pharma, Germany, veterinary medicine), distilled water (Zentiva SA, Romania), adrenaline Therapy $1 \mathrm{mg} / \mathrm{ml}$ solution for injection adrenaline (SA Therapy, Romania).

Adrenaline and distilled water were administered as solutions in conjunctival instillations, and ketamine was administered by injection, intraperitoneally.
A Nikon stereomicroscope, model SMZ 1270, connected to a Mshot video camera, model MSX2-C, was used to visualize the corneal blood vessels, and the video camera was connected to a computer. The video camera was equipped with an intermediate lens attached to the front of the sensor to compensate for the magnification given by the stereomicroscope eyepieces. The system was manually calibrated using the "Mshot Imaging Analysis System" software and the Nikon micrometric calibration blade, type B (1 Div $=0.1 \mathrm{~mm}=100 \mu \mathrm{m}), \mathrm{J} 28004$ series. The total magnification was $400 \mathrm{X}$.

The anesthetized rats were placed in lateral decubitus in a restraint device to have optimal access to the eyeball to be examined, and the eyelid slit was kept open by manual traction. The examination was performed for each eye that developed corneal neovascularization. Image recording was performed at set time intervals of 60 to 60 seconds over a period of 630 seconds. To have the same magnification factor, the records were made from the same working distance for each eye, and then the data were processed. 12 images were saved as jpg files for each eye. The images were processed in the Mshot Imaging Analysis System program.

The substances to be researched were applied in the conjunctival sac by instillation, without touching the ocular surface, at moments T1 and T6. A drop of distilled water was administered 30 seconds after the start of the recording, and a drop of $1.5 \mathrm{mmol} / \mathrm{L}$ adrenaline solution was administered at 330 seconds. Moments T1 and T6 were not analyzed. The vascular diameter measurement moments were: T0 $(0$ seconds), T1 (30 seconds), T2 (90 seconds), T3 (150 seconds), T4 (210 seconds), T5 (270 seconds), T6 (330 seconds), T7 (390 seconds), T8 (450 seconds), T9 (510 seconds), T10 (570 seconds) and T11 (630 seconds). Moments T1 and T6, when the substances to be investigated were applied, were not analyzed.

The parameters followed were variations in vascular caliber (vasodilation/ vasoconstriction), and the measurements were expressed in micrometers.

For each eye, respectively for each image of the chosen moment T0-T11, 3 measurements of the external diameter were performed at the same points for which the average was calculated. Subsequently, for each moment of each determination, the percentage variation of the diameter of the new blood vessels relative to the time $\mathrm{T} 0$ was calculated according to the following formula:

$$
\text { Drel }=\left(\frac{D x-D 0}{D 0}\right) \times 100
$$

where Drel represents the mean of the percentage variation of the blood vessel diameter from the moment T0, Dx represents the diameter in $\mu \mathrm{m}$ of the blood vessel at the measured moment, and D0 
represents the diameter of the blood vessel in $\mu \mathrm{m}$ from the moment $\mathrm{T} 0$.

The positive values of Drel are represented by the increases in the diameter (vasodilation), while the negative values are the expression of the decrease of the vascular diameter (vasoconstriction).

The mean and the standard error were calculated for each batch and each moment of the determinations. Using the T-Student test, the variant for paired samples (2-tailed, 1 paired), the statistical significance of the difference between each moment and the T0 moment was calculated, comparing Drel with the value from the T0 moment. The results were considered statistically significant if $\mathrm{p}<0.05$.

\section{Results}

After administration of distilled water at time T1, the mean percentage change in blood vessel diameter \pm standard error was $-0.28 \pm 0.92$ at time $\mathrm{T} 2,-0.43 \pm$ 0.87 at time $\mathrm{T} 3,0.89 \pm 0.8$ at time $\mathrm{T} 4$, and $0.57 \pm 1.1$ at time $\mathrm{T} 5$, the differences being statistically insignificant compared to time T0. After administration of adrenaline $1.5 \mathrm{mmol} / \mathrm{L}$ at time T6, the mean percentage change in vascular diameter \pm standard error was $-4.5 \pm 4.38$ at time $\mathrm{T} 7,-15.59 \pm$ 7.82 at time T8, $-33.32 \pm 8.7$ at time T9, $-46.72 \pm 9.72$ at time $\mathrm{T} 10$, and $-40.71 \pm 8.88$ at time T11, for the last 3 values the differences being statistically significant compared to time T0. At the T11 moment, the vascular diameter for 2 of the examined eyes decreased so much that the optical-electronic system used for recording no longer allowed its measurement. The results are presented in Table $\mathbf{3}$ and Fig. 1.

Table 3. Evolution over time of the mean percentage change in the diameter of the corneal blood vessels after the administration of distilled water at time T1, respectively after the administration of adrenaline $1.5 \mathrm{mmol} / \mathrm{L}$ at time T6

\begin{tabular}{|c|c|c|c|c|c|c|c|c|c|c|}
\hline \multirow{13}{*}{ 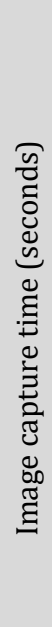 } & Specimen & 1 & 2 & 3 & 4 & 5 & 6 & Mean & Std.Er. & $\mathrm{p}$-value \\
\hline & T0 & 0 & 0 & 0 & 0 & 0 & 0 & 0 & 0 & 0 \\
\hline & \multicolumn{10}{|c|}{ T1 -30s- Administration of distilled water } \\
\hline & $\mathrm{T} 2-90 \mathrm{~s}$ & 2.94 & 0 & -1.33 & 1.66 & -2.08 & -2.86 & -0.28 & 0.92 & 0.77 \\
\hline & T3 - 150s & 2.94 & 0 & -2.66 & 0 & 0 & -2.86 & -0.43 & 0.87 & 0.64 \\
\hline & $\mathrm{T} 4-210$ & 2.94 & 3.7 & -1.33 & 0 & 0 & 0 & 0.89 & 0.8 & 0.32 \\
\hline & T5 - 270s & 1.47 & 3.7 & -2.66 & 1.66 & 2.08 & -2.86 & 0.57 & 1.1 & 0.63 \\
\hline & \multicolumn{10}{|c|}{ T6 - 330s- Adrenaline administration } \\
\hline & T7 - 390s & 8.82 & 0 & -10.66 & -21.66 & 2.08 & -5.55 & -4.5 & 4.38 & 0.35 \\
\hline & $\mathrm{T} 8-450 \mathrm{~s}$ & 8.82 & -14.81 & -9.33 & -40 & -2.08 & -36.11 & -15.59 & 7.82 & 0.10 \\
\hline & T9-510s & -14.7 & -18.52 & -9.33 & -48.33 & -56.25 & -52.77 & -33.32 & 8.7 & 0.01 \\
\hline & $\mathrm{T} 10-570 \mathrm{~s}$ & -42.64 & -22.22 & -18.66 & -61.66 & -54.58 & -80.55 & -46.72 & 9.72 & 0.004 \\
\hline & T11 -630s & -41.17 & -33.33 & -23.33 & -65 & DNM & DNM & -40.71 & 8.88 & 0.019 \\
\hline
\end{tabular}

Std.Er. $=$ Standard error, DNM = non-measurable diameter

\section{Discussions}

The model of corneal neovascularization is the result of research done to investigate sodium selenite-induced cataract in 15-day-old rat pups in which, for microscopic study of lens opacities, general anesthesia was performed with ketamine at a dose of $150 \mathrm{mg} / \mathrm{kg}$ body weight and in which in vivo study of lens transparency changes was no longer possible due to the occurrence of changes in corneal transparency (Fig. 2). The determining factor in the production of corneal changes was further investigated, and the conclusion was that ketamine is responsible for these changes in corneal transparency, which is consistent with existing data in literature [44-47].

The results presented above showed that the administration of adrenaline produces a statistically significant decrease in the diameter of the blood vessels (vasoconstriction). In two of the eyes examined, the vasoconstriction was so intense that the measurement of the vascular diameter was no longer possible. The administration of distilled water did not produce statistically significant changes in vascular diameter. These allowed us to assume that there are $\alpha$-adrenergic receptors at the level of the corneal blood vessels, whose stimulation classically produces vasoconstriction.

Following these results, we cannot exclude the existence of $\beta$-adrenergic receptors whose stimulation produces vasodilation. The vasoconstriction found above may be an algebraic sum between the vasoconstrictor effect produced by stimulating $\alpha$-adrenergic receptors and the vasodilatory effect produced by stimulating $\beta$ adrenergic receptors if the vasodilatory effect is less intense than the vasoconstrictor effect. 


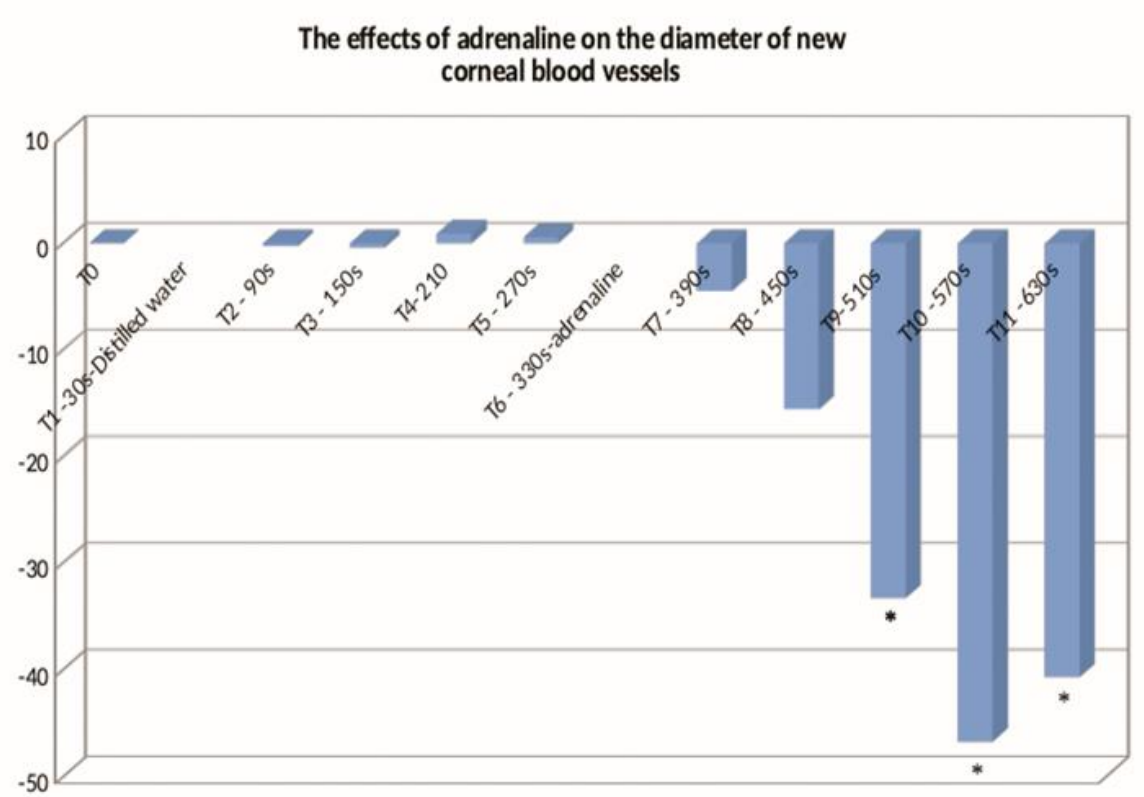

Fig. 1 The evolution over time of the mean percentage change of vascular diameter after the administration of distilled water at the moment $\mathrm{T} 1$, respectively after the administration of adrenaline $1.5 \mathrm{mmol} / \mathrm{L}$, at the moment T6. The moments at which the determinations were performed are represented horizontally, the mean percentage variation of the vascular diameter is represented vertically. There were statistically significant changes for moments $\mathrm{T} 9, \mathrm{~T} 10$, and $\mathrm{T} 11$ $(* \mathrm{p}<0.05)$

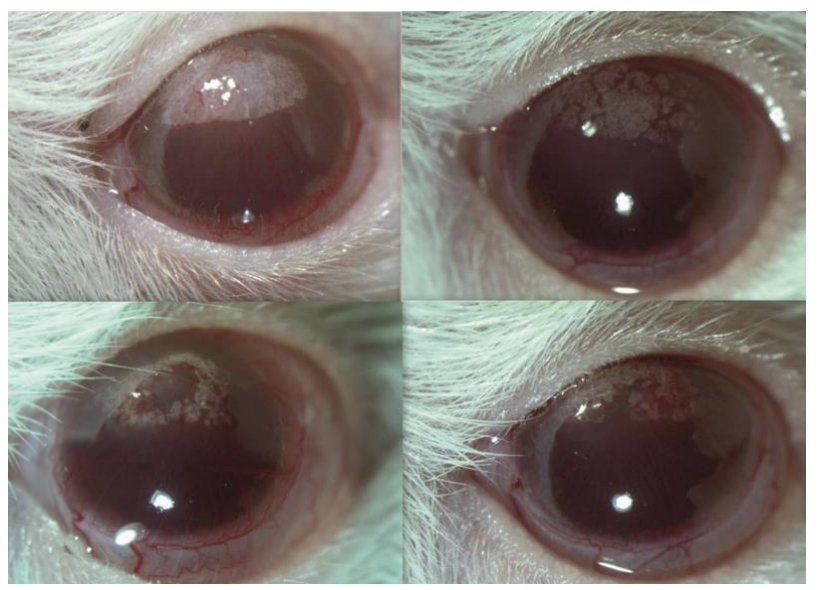

Fig. 2 Images showing change transparency and corneal blood vessels

\section{Conclusions}

1. Administered in conjunctival instillations, adrenaline produces vasoconstriction in the corneal blood vessels.

2. In our experimental conditions, there were $\alpha$ adrenergic receptors in the corneal blood vessels.

3 . It is possible that there are also $\beta$-adrenergic receptors in the corneal blood vessels, but whose stimulation produces lower intensity vasodilation, masked by the vasoconstrictor effect produced by the stimulation of $\alpha$-adrenergic receptors.

\section{Conflict of Interest}

Authors state no conflict of interest.

\section{Acknowledgements}

None.

\section{Sources of Funding}

None.

\section{Disclosures}

None.

\section{References}

1. Ahlquist RP. A study of the adrenotropic receptors. Am J Physiol. 1948; 153:586-600.

2. Arbilla S, Langer SZ. Differences between presynaptic and postsynaptic alpha-adrenoceptors in the isolated nictitating membrane of the cat: effects of metanephrine and tolazoline. Br J Pharmacol. 1978; 64:259-264.

3. McGrath J, Wilson V. Alpha-adrenoceptor subclassification by classical and response-related methods: same question, different answers. Trends Pharmacol Sci. 1988; 9:162-165.

4. Mitrano DA, Schroeder JP, SmithY, Cortright JJ, Bubula $N$, Vezina P, Weinshenker D. $\alpha-1$ Adrenergic receptors are localized on presynaptic elements in the nucleus accumbens and regulate mesolimbic dopamine transmission. Neuropsychopharmacology. 2012; 37:2161-2172.

5. Molinoff PB. Alpha- and beta-adrenergic receptor subtypes properties, distribution and regulation. Drugs.1984; 28 Suppl 2:1-15.

6. Kaumann AJ, Molenaar P. Modulation of human cardiac function through $4 \beta$-adrenoceptor populations. Naunyn Schmiedebergs Arch Pharmacol. 1997; 355:667-681.

7. Wachter SB, Gilbert EM. Beta-adrenergic receptors, from their discovery and characterization through their manipulation to beneficial clinical application. Cardiology. 2012; 122:104-112.

8. Furchgott RF. The receptors for epinephrine and norepinephrine (adrenergic receptors). Pharmacol Rev. 1959; 11:429-441.

9. Fulga I. Chapter 11. The Adrenergic System. Pharmacology, second edition revised and added, 2015, Bucharest, Medical Publishing House, 158-180. 
10. Klyce SD, Wong RK. Site and mode of adrenaline action on chloride transport across the rabbit corneal epithelium. J Physiol. 1977; 266:777-799.

11. Walkenbach RJ, Ye GS, Reinach PS, Boney F. Alpha 1adrenoreceptors in human corneal epithelium.Invest Ophthalmol Vis Sci. 1991; 32:3067-3072.

12. Grueb M, Bartz-Schmidt KU, Rohrbach JM. Adrenergic regulation of cAMP/protein kinase A pathway in corneal epithelium and endothelium. Ophthalmic Res. 2008; 40:322328.

13. Ishikawa H, Miller DD, Patil PN. Comparison of postjunctional alpha-adrenoceptors in iris dilator muscle of humans, and albino and pigmented rabbits. Naunyn Schmiedebergs Arch Pharmacol. 1996; 354:765-772.

14. Ruan Y, Böhmer T, Jiang S, Gericke A. The Role of Adrenoceptors in the Retina. Cells. 2020; 9:2594.

15. Zetterström C, Hahnenberger R. Pharmacological characterization of human ciliary muscle adrenoceptors in vitro. Exp Eye Res. 1988; 46:421-430.

16. Enríquez de Salamanca A, Siemasko KF, Diebold Y, Calonge M, Gao J, Juárez-Campo M, Stern ME. Expression of muscarinic and adrenergic receptors in normal human conjunctival epithelium. Invest Ophthalmol Vis Sci. 2005; 46:504-513.

17. Walkenbach RJ, Ye GS, Reinach PS, Boney F. Alpha 1adrenoceptors in the corneal endothelium. Exp Eye Res. 1992; 55:443-450.

18. Bylund DB, Chacko DM. Characterization of alpha2 adrenergic receptor subtypes in human ocular tissue homogenates. Invest Ophthalmol Vis Sci.1999; 40:22992306.

19. Matsuo T, Cynader MS. Localization of alpha- 2 adrenergic receptors in the human eye. Ophthalmic Res. 1992; 24:213219.

20. Kalapesi FB, Coroneo MT, Hill MA. Human ganglion cells express the alpha-2 adrenergic receptor: relevance to neoroprotection. Br J Ophthalmol. 2005; 89:758-763.

21. Diebold Y, Enríquez de Salamanca A, Calonge M, Sáez V, Callejo S, Stern ME. Alpha2-adrenergic receptors are present in normal human conjunctiva. Curr Eye Res. 2005; 30:1121-1129.

22. Stamer WD, Huang Y, Seftor RE, Svensson SS, Snyder RW, Regan JW. Cultured human trabecular meshwork cells express functional alpha $2 \mathrm{~A}$ adrenergic receptors. Invest Ophthalmol Vis Sci. 1996; 37:2426-2433.

23. Wax MB, Molinoff PB. Distribution and properties of betaadrenergic receptors in human iris-ciliary body. Invest Ophthalmol Vis Sci. 1987; 28:420-430.

24. Yu DY, Su EN, Cringle SJ, Alder VA, Yu PK, Desantis L. Effect of betaxolol, timolol and nimodipine on human and pig retinal arterioles. Exp Eye Res. 1998; 67:73-81.

25. Wax MB, Molinoff PB, Alvarado J, Polansky J.Characterization of beta-adrenergic receptors in cultured human trabecular cells and in human trabecular meshwork. Invest Ophthalmol Vis Sci. 1989; 30:51-57.

26. Messina Baas O, Pacheco Cuellar G, Toral-López J, Lara Huerta SF, Gonzalez-Huerta LM, Urueta-Cuellar H, RiveraVega MR, Babayan-Mena I, Cuevas-Covarrubias SA. ADRB1 and ADBR2 gene polymorphisms and the ocular hypotensive response to topical betaxolol in healthy Mexican subjects. Curr Eye Res. 2014; 39:1076-1080.

27. Elena PP, Denis P, Kosina-Boix M, Saraux H, Lapalus P. Beta adrenergic binding sites in the human eye: an autoradiographic study. J Ocul Pharmacol. 1990; 6:143-149.

28. Steinle JJ, Booz GW, Meininger CJ, Day JN, Granger HJ. Beta 3adrenergic receptors regulate retinal endothelial cell migration and proliferation. J Biol Chem. 2003; 278:2068120686.

29. Graham RM, Perez DM, Hwa J, Piascik MT. $\alpha_{1}$-Adrenergic Receptor Subtypes. Molecular Structure, Function, and Signaling. Circ Res. 1996; 78:737-749.
30. Taylor BN, Cassagnol M. Alpha Adrenergic Receptors. 2020, StatPearls, Treasure Island (FL), StatPearls Publishing.

31. Godfraind T, Miller RC, Lima JS. Selective alpha 1-and alpha 2adrenoceptor agonist-induced contractions and 45Ca fluxes in the rat isolated aorta. Br J Pharmacol. 1982; 77:597-604.

32. Wei L, Zhu YM, Zhang YX, Liang F, Jia H, Qu CL, Wang J, Tang JS, Lu SM, Huo FQ, Yan CX. Activation of $\alpha 1$ adrenoceptors in ventrolateral orbital cortex attenuates allodynia induced by spared nerve injury in rats. Neurochem Int. 2016; 99:85-93.

33. Desiniotis A, Kyprianou N. Advances in the design and synthesis of prazosin derivatives over the last ten years. Expert Opin Ther Targets. 2011; 15:1405-1418.

34. Lepor H. Alpha-blockers for the Treatment of Benign Prostatic Hyperplasia.Urol Clin North Am. 2016; 43:311-323.

35. Giovannitti Jr. JA, Thoms SM, Crawford JJ. Alpha-2 adrenergic receptor agonists: a review of current clinical applications. Anesth Prog. 2015; 62:31-39.

36. Hoffmann C, Leitz MR, Oberdorf-Maass S, Lohse MJ, Klotz KN. Comparative pharmacology of human beta-adrenergic receptor subtypes-characterization of stably transfected receptors in CHO cells. Naunyn Schmiedebergs Arch Pharmacol. 2004; 369:151-159.

37. Schiffelers SL, van Harmelen VJ, de Grauw HA, Saris WH, van Baak MA. Dobutamine as selective beta (1)adrenoceptor agonist in in vivo studies on human thermogenesis and lipid utilization. J Appl Physiol. 1999; 87:977-981.

38. Farzam K, Jan A. Beta Blockers. 2020, StatPearls, Treasure Island (FL), StatPearls Publishing.

39. Louis SN, Nero TL, Iakovidis D, Jackman GP, Louis WJ. LK 204-545, a highly selective beta1-adrenoceptor antagonist at human beta-adrenoceptors. Eur J Pharmacol. 1999; 367:431435.

40. Svedmyr N. Fenoterol: a beta2-adrenergic agonist for use in asthma. Pharmacology, pharmacokinetics, clinical efficacy and adverse effects. Pharmacotherapy. 1985; 5:109-126.

41. 41. Arai M, Sato T, Takeuchi S, Goto S, Togari A. Dose effects of butoxamine, a selective $\beta 2$-adrenoceptor antagonist, on bone metabolism in spontaneously hypertensive rat. Eur J Pharmacol. 2013; 701:7-13.

42. Schena G, Caplan MJ. Everything You Always Wanted to Know about $\beta_{3}-\mathrm{AR} *\left({ }^{*}\right.$ But Were Afraid to Ask). Cells. 2019; 8:357.

43. Ballester C, Sarriá B, García-Granero E, Mata M, Milara J, Morcillo EJ, Lledó S, Cortijo J. Relaxation by beta 3adrenoceptor agonists of the isolated human internal anal sphincter. Life Sci. 2010; 86:358-364.

44. Koehn D, Meyer KJ, Syed NA, Anderson MG. Ketamine/Xylazine-Induced Corneal Damage in Mice. PLoS One. 2015; 10(7):e0132804.

45. Kufoy EA, Pakalnis VA, Parks CD, Wells A, Yang CH, Fox A. Keratoconjunctivitis sicca with associated secondary uveitis elicited in rats after systemic xylazine/ketamine anesthesia. Exp Eye Res. 1989; 49:861-871.

46. Turner PV, Albassam MA. Susceptibility of rats to corneal lesions after injectable anaesthesia. Comp Med. 2005; 55:175-182.

47. Tita B, Leone MG, Casini ML, Corubolo C, Bordi F, Guidolin D, Fumagalli E, Romanelli L, Mattioli F, Fehér J, Saso L. Corneal toxicity of xylazine and clonidine, in combination with ketamine, in the rat. Ophthalmic Res. 2001; 33:345-352. 